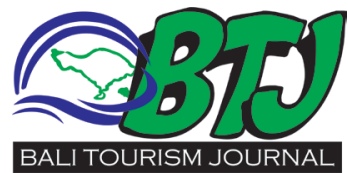

\title{
COVID 19 Forced cancelation of Uluwatu Cliff's Fortification
}

\author{
Ida Ayu Putu Widya Indah Sari ${ }^{1}$
}

\section{ABSTRACT}

Badung Regency Government forced to postpone several projects in 2020 due to COVID-19 pandemic. Uluwatu temple, a gem in Bali's southern part, became one of many sites that need to be maintained. Above all, a viral photo about the Uluwatu cliff in 2019 made the public's attention focused on the iconic tourism spot. The circulated image depicted a massive crack on the rocky height at the side of the Uluwatu temple. The Manager, I Wayan Wijana, admitted that there is a crack on cliffs at Uluwatu Temple. Furthermore, it has been there for decades. According to observers, in 1992, there was an insignificant decrease of about one millimeter. Although Uluwatu cliff's crack has been there for decades, there was no significant government action. Local authorities decided to reduce the number of prayer visits during ceremonies and center tourism activities in the outer temple area to prevent any accidents. Besides, the Badung regency government had conducted few patches on the cliffside, with a regular annual inspection. Finally, In 2019, the Government of Badung invited potential quotation to fortify the Temple's base. Nevertheless, there was no final announcement regarding the quotation winner. In the second quarter of 2020, Badung Public Works and Spatial Planning Agency announced a temporary suspension on several infrastructure projects due to budget allocation for COVID-19 handling. The announcement confirmed that the Uluwatu fortification project would not be conducted in the year.

Keyword: Uluwatu Cliff, Crack, Badung Regency

Cite This Article: Sari, I.A.P.W.I. COVID 19 Forced cancelation of Uluwatu Cliff's Fortification. Bali Tourism Journal (BTJ) 2020, 4(1): 23-26. DOI : $10.36675 /$ btj.v4i2.43

'Pro 1 RRI Denpasar widyaindahsari01@gmail.com

\section{Editor:}

Ida Bagus Ngurah Tri Pramana
Received : 2020-03-22 Accepted : 2020-04-30 Published: 2020-06-05

\section{BACKGROUND}

Badung Regency Government forced to postpone several projects in 2020 due to COVID 19 pandemic. The local authority scheduled 2020 to be the most productive year since many tourism objects in Badung should be maintained, and new spots need to be erected. Uluwatu temple, a gem in Bali's southern part, became one of many sites that need to be maintained. Uluwatu area holds significant meaning to the surrounding community. The area had a positive impact, such as developing socio-economic activities, developing sociocultural activities, the emergence of new arts, and increasing tourist visits to the area. Nevertheless, apart from positive impacts, regional development has negative impacts; there were conflicts over land issues, displacement of smallholders, community helplessness, disharmony of relations between some parties, disrupted freedom of ritual activities, and the emergence of new powers. ${ }^{1}$ Above all, a viral photo about the Uluwatu cliff in 2019 made the public's attention focused on the iconic tourism spot. Uluwatu temple is an important temple for Balinese Hindus as well as a famous tourist attraction in Bali. The main attraction is the Temple's location on top of a 70 meters high and steep cliff. Tourists also favor the Temples because of the Temple's background view: A blue turquoise
Indian Ocean that expands to the horizon is a rare scenery to behold. Due to the cliff position facing west, tourists can freely witness the sunset without any blocking if the weather is clear.

\section{AUTHORITY'S RESPONSES TO THE CRACK}

The Manager of Uluwatu Temple Tourist Attraction responded to a viral photo of the Uluwatu cliff. The circulated image depicted a massive crack on the rocky height at the side of the Uluwatu temple. The Manager, I Wayan Wijana, assured that the picture did not match the current conditions. According to him, the image showed dried and withered plants on the cliff, whereas currently, the peaks are overgrown with naturally fertile vegetations. However, Wijana admitted that there is a crack on cliffs at Uluwatu Temple. Furthermore, it has been there for decades. According to observers, in 1992, there was an insignificant decrease of about one millimeter.

According to the cosmological concept of Hindu temples in Bali, Uluwatu Temple is one of the Sad Kahyangan: The six high temples that become the worship of all Hindus in Bali. Official publication of the Bali Regional Government, The Bali Regional Monograph, states that the Sad Kahyangan Temple was established to serve the worship of rural residents during the days of the original Balinese 


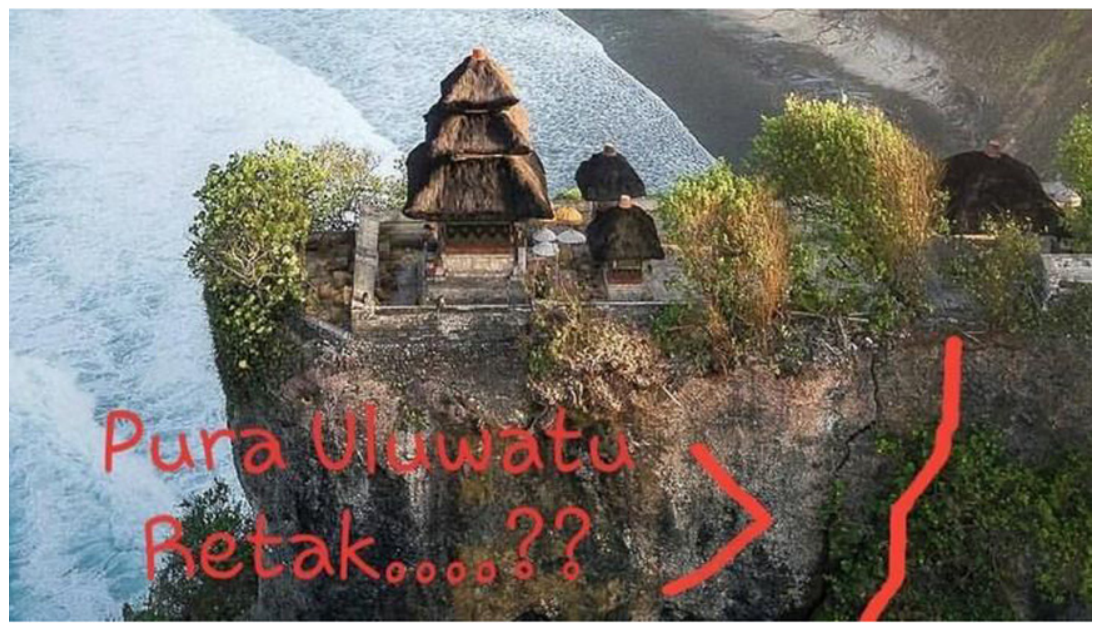

Figure 1. A viral photo about the Uluwatu cliff in 2019, The image depicted a massive crack on the rocky height at the side of the Uluwatu temple. ${ }^{4}$

village. ${ }^{2}$ To prevent an accident, He explained since 1992 to hitherto; the management has been limiting visitors, especially during the Piodalan ritual at the Temple by the card system. For tourists, the authority prohibited them to enter the central area. Instead, they offer the Uluwatu Temple's outer area as a tourist attraction. Thus, the rift would not have a significant effect on the tourism sector. ${ }^{3}$

The area's authority prohibits any visitor except prayer to enter the inner Temple. Due to its fame as one of Balitourism's icons, the management admitted that it was a great challenge to limit tourist visits. Hitherto, any tourist's activity is centered at the outer area, hoping it would not significantly affect the rift. Wijana explained Badung Public Works and Public Housing Office has been conducting an annual evaluation. Furthermore, a master plan to restructure the Uluwatu cliff has been designed. The blueprint encompasses cliff strengthening, wall relocation, and an abrasion management plan.

A few years back, the local Government had patched the cliff gap, but several prominent unpatched spots were visible. The issue was heatedly discussed during A.A. Gde Agung and Sudikerta period $(2005$ - 2013) when a maintenance project was on the cliff. On Wednesday, 9 January 2019, Acting Secretary of Bali Provincial regional disaster management agency, Made Rentin confirmed that the cracks had been there for a while. As for the cause, it was unknown. He proposed an in-depth study by consulting geology to find the answer. Rentin added, according to Uluwatu Temple officials, there was no additional stretching on the crack. Thus he believed Uluwatu Temple is relatively safe to visit. Besides, He appealed to the broader public to stay vigilant since it is difficult to restrict the visitor's number. The cliff maintenance was under the authority of the Badung Regency Government as a related stakeholder. It is expected that the study between the Badung Regency Government and geologists can find a solution to suppress the Uluwatu cliff rift. ${ }^{6}$

\section{THE PROJECT UNCERTAINTY}

Besides serving as a ritual place, The Temple may act as a social, educational (education) and recreational site. The social function reflects on the harmonious relationship between Pecatu Village people, especially with local, domestic and foreign tourists. Also, the area of Uluwatu Temple is often used as a place for social activities by residents in particular. Second, Uluwatu Temple, as a memorial, has potential resources that can be utilized by the community, especially the younger generation, related to historical learning resources. One of them is developing learning education outside the classroom by making visits (observations) to historical objects, for example, monuments, museums, temples, historic places, and so on.? The Badung Regency Government planned to allocate IDR 29 billion for the Uluwatu Temple. The earmarked fund was to rearrange the entire area of the Uluwatu Temple. Pecatu Indigenous community chief, Jro Sumerta, confirmed the Government had budgeted IDR 29 billion for cliff structuring and road access. The budget would be used for all areas arrangement, including inside and outside the tourist objects around Uluwatu Temple. Sumerta added, damages also occurred one kilometer from the Temple, on the northern cliffside. ${ }^{8}$

On 17 June 2019, The Badung Regency Government has invited an open quotation project to repair the rift on the Uluwatu cliff. Before working on the Uluwatu cliff wall reinforcement project, Badung Public Works and Spatial Planning Agency (PUPR) conducted construction and management analysis with Construction Consultant of PT Inakko Internasional Konsulindo. From the study, the construction material would be anti-corrosion steel anchors, steel nets and steel slings. In the process, drilling would be necessary for anchor installation. Then Steel ties and rock gap grouting with adhesive cement. The project would be similar to sew and glue the cliff. The project was expected to be completed within four months in 2019. However, Until Thursday, 27 June 2019, none registered as a participant. The plead for quotation was registered under Capital Expenditure for Roads, Irrigation and the Procurement Network for River Safeguards, Cliff Reinforcement Buildings, Uluwatu Cliff Wall Reinforcement funding. The 


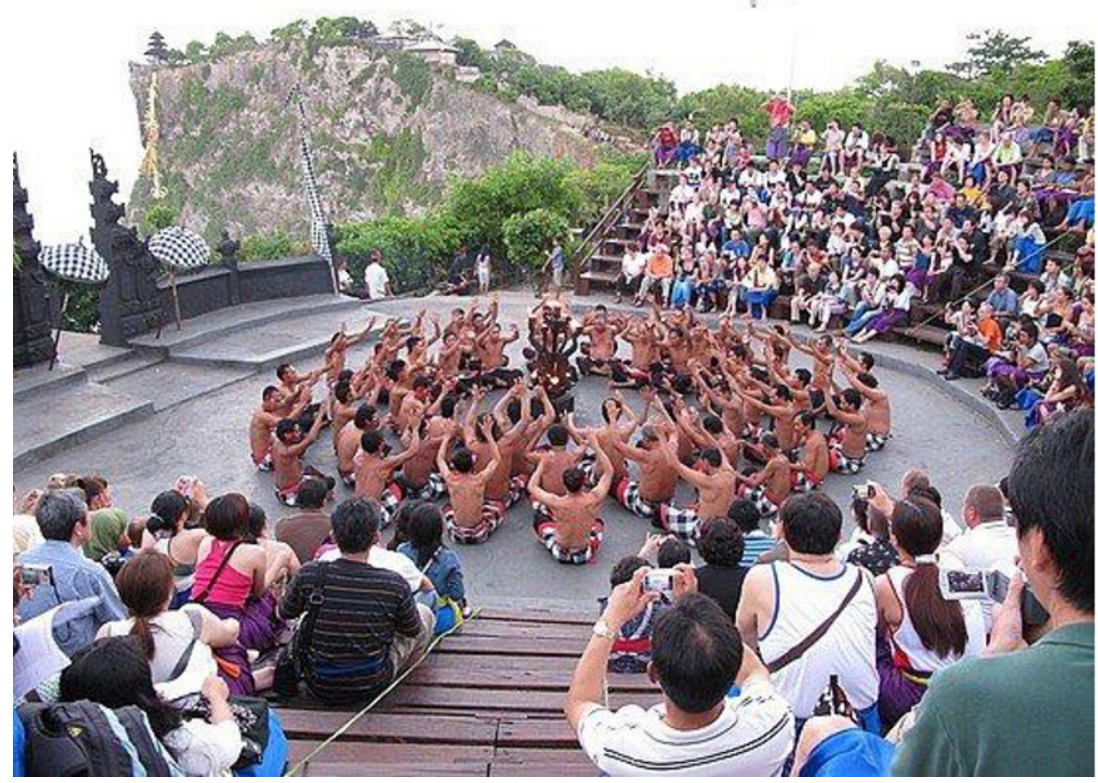

Figure 2. Kecak Dance, a popular tourist attraction at Uluwatu. ${ }^{10}$

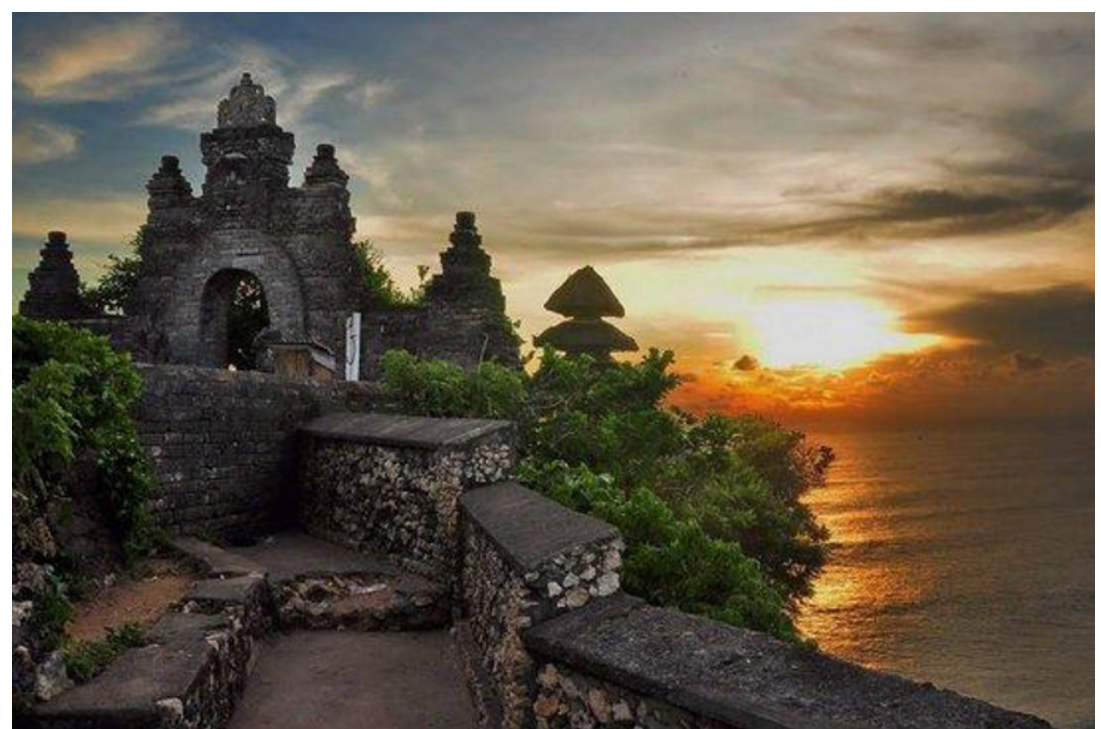

Figure 3. Iconic Sunset View of Uluwatu. ${ }^{13}$

total budget needed was IDR 29,500,000,000. Head of the Water Resources Division, Badung Public Works and Spatial Planning Agency, Agung Dalem, confirmed. Furthermore, he claimed, it was the final week; thus, next week would be planned as the submitting phase to the Public works agency. Should the quotation failed to meet, his party would conduct a further discussion with the stakeholders. ${ }^{9}$

\section{DELAYED PROJECT}

In the second quartal of 2020, Badung Public Works and Spatial Planning Agency temporarily suspended several infrastructure projects. It was an urged decision due to budget allocation for
COVID-19 handling. The postponed plan was including Uluwatu cliffs's fortification project in Pecatu. The Head of the Water Resources Division of the Badung Regency Public Works and Spatial Planning Department, Sriasih, confirmed the information on Tuesday, 21 July 2020. Sriasih admitted that the Uluwatu project was not the only delayed project. Some projects, such as Bung Karno Park in Penarungan Village, Delta Park in Dalung, experienced a similar fate.

Regarding the postponed decision, Sriasih could not give further information on when the 2019 project would be restarted. She assured the project would be strived to be submitted again once the budget condition is stable. The Uluwatu project had proceeded to the quotation phase at the Electronic Procurement Service in Badung Regency. However, there was no final announcement regarding the winner. Plans to strengthen Uluwatu cliffs, under Uluwatu Temple, have been long discussed by the regencial Government. The previous patching had been done during Regent A.A. Gde Agung (2005 - 2013). In 2015, there was an emerging rumor to strengthen the cliffs by injection. After two years, the project finally reached the quotation phase without any announced winner. the Construction Consultant of PT Inakko Internasional Konsulindo stated The project would spend IDR 29.5 billion funds. ${ }^{11,12}$

Regent of Badung Region's decree No. 2039 of 2012 pointed the Traditional Village of Pecatu as the Manager of the tourist attraction in the Uluwatu Temple environment. ${ }^{14}$ Pecatu indigenous village authority has been restricting prayer visits to the main temple area. Furthermore, the delayed fortification plan made them vigilant. Pecatu Indigenous village leader, I Made Sumerta, on Wednesday 22 July 2020, said he entirely accepted Government's decision to postpone the cliff fortification plan. As a Badung Regency parliament member, he realized the people were worried about the cliff cracks' condition. Therefore, to reduce the main temple visitor is a reasonable option. Previously, the prayer in the main temple area may reach 100 people. Due to the condition, it has been minimizing to 25 people. Further, Sumerta added that the expert team had conducted a study. If the fortifying project is an emergency, it should be executed immediately. ${ }^{15}$

\section{CONCLUSION}

Although Uluwatu cliff's crack has been there for decades, there was no significant government action to handle the condition. Local authorities decided to reduce the number of prayer visits 
during ceremonies and center tourism activities in the outer temple area to prevent any accidents. Besides, the Badung regency government had conducted few patches on the cliffside, with a regular annual inspection. In 2019, the Government of Badung invited potential quotation to fortify the Temple's base. Nevertheless, there was no final announcement regarding the quotation winner. In the second quarter of 2020, Badung Public Works and Spatial Planning Agency announced a temporary suspension on several infrastructure projects due to budget allocation for COVID-19 handling. The announcement confirmed that the Uluwatu fortification project would not be conducted in the year.

\section{REFERENCES:}

1. IM Adhika. Dampak Komodifikasi Daya Tarik Wisata di Desa Pecatu, Kuta Selatan, Bali. Skripsi Universitas Udayana. 2006.

2. KAJ Putra, PN Chrisnapati, MWA Kesiman, \& IGM Darmawiguna. Augmented Reality Book Pengenalan Tata Letak Bangunan Pura Luhur Uluwatu beserta Landscape Alam. KARMAPATI (Kumpulan Artikel Mahasiswa Pendidikan Teknik Informatika). 2019. 3(4), 279-289.

3. R Kustiani. Viral Foto Tebing Pura Uluwatu Bali Retak, Benar tapi Salah. Tempo[dot]co. 2019. Available at URL: https://travel.tempo.co/read/1163649/viral-foto-tebingpura-uluwatu-bali-retak-benar-tapi-salah/full\&view=ok

4. Image from B Febrylian '[BENAR] VIRAL FOTO TEBING ULUWATU BALI RETAK, PIHAK PENGELOLA BERIKAN KLARIFIKASI'. Turnbackhoax[dot]id. 2019. Available at URL: https:/turnbackhoax.id/2019/01/11/ benar-viral-foto-tebing-uluwatu-bali-retak-pihakpengelola-berikan-klarifikasi/

5. NF yusuf. Pengelola wisata Uluwatu tanggapi foto tebing retak. Antara Bali. 2019. Available at URL: https://bali. antaranews.com/berita/135234/pengelola-wisata-uluwatutanggapi-foto-tebing-retak

6. A Mardiastuti. Fakta di Balik Hebohnya Tebing Pura Uluwatu Bali Retak. Detik News. 2019. Available at URL: https://news.detik.com/berita/d-4376727/fakta-di-balikhebohnya-tebing-pura-uluwatu-bali-retak

7. W Sanjaya. Strategi Pembelajaran Berorientasi Standar Proses Pendidikan. Jakarta : Kencana Prenada Media. 2006.
8. NLPC Yastari. PURA ULUWATU DI DESA PECATU, KECAMATAN KUTA SELATAN, BADUNG, BALI (Studi Tentang Perkembangan Pura Sebagai Destinasi Pariwisata serta Kontribusinya Bagi Pendidikan Sejarah). Widya Winayata: Jurnal Pendidikan Sejarah. 2013. 1(1).

8. Anonymous. Tebing Retak, Badung Siapkan Dana Rp 29 M Untuk Penataan Pura Uluwatu. Radar Bali. 2019. Available at URL: https://radarbali.jawapos.com/ $\mathrm{read} / 2019 / 01 / 09 / 112697 /$ tebing-retak-badung-siapkandana-rp-29-m-untuk-penataan-pura-uluwatu.

9. IKA Aryanta. Biaya Perbaikan Retakan Tebing Uluwatu Rp 29,5 M Namun Bisa Terancam Gagal, Ini Sebabnya. Tribun-bali[dot]com. 2019. Available at URL: https://bali. tribunnews.com/2019/06/28/biaya-perbaikan-retakantebing-uluwatu-rp-295-m-namun-bisa-terancam-gagalini-sebabnya?page $=$ all.

10. Image Uluwatu Kecak Dance. Available at URL: http:// www.uluwatukecakdance.com/

11. Anonymous. Anggaran Terbatas, Proyek Penguatan Tebing Uluwatu Tertunda. Baliexpress. 2020. Available at URL: https://baliexpress.jawapos.com/read/2020/07/21/205253/ anggaran-terbatas-proyek-penguatan-tebing-uluwatutertunda

12. Anonymous. Covid-19, Anggaran Dipangkas, Proyek Penguatan Tebing Uluwatu Batal. Radar Bali. 2020. Available at URL: https://radarbali.jawapos.com/ read/2020/07/22/205389/covid-19-anggaran-dipangkasproyek-penguatan-tebing-uluwatu-batal

13. Image by Veni Vidi Bali 'Sunset @Uluwatu Temple'. 2014. Available at URL: https://www.tripadvisor. co.id/Location PhotoDirectLink-g469404-d6884747i104214379-Bali_Sweet_Holidays-Seminyak_Kuta_ District_Bali.html.

14. Bupati Kepala Daerah Tingkat II Badung. 2012. Keputusan Bupati Nomor 2039 Tahun 2012.

Tentang Penunjukan Pengelolaan Daya Tarik Wisata Kawasan Luar Pura Uluwatu. Disparda Bali. 2012. Statistik Pariwisata Bali 2012. Denpasar: Disparda Bali.

15. IKA Aryanta. Proyek Jahit Tebing Batal, Pemedek di Utama Mandala Pura Uluwatu Dibatasi 25 Orang. Tribun-bali[dot] com. 2020. Available at URL: https://bali.tribunnews. com/2020/07/23/proyek-jahit-tebing-batal-pemedek-diutama-mandala-pura-uluwatu-dibatasi-25-orang.

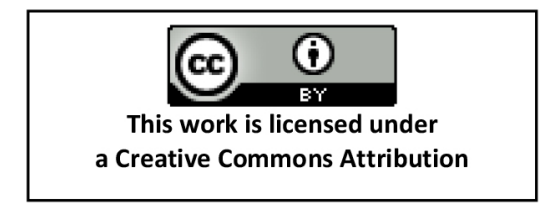

